\title{
Surgical Site Infection
}

National Cancer Institute

\section{Source}

National Cancer Institute. Surgical Site Infection. NCI Thesaurus. Code C112019.

An infection that occurs at a surgical site within 30 days after an operation. 